University of Nebraska - Lincoln

DigitalCommons@University of Nebraska - Lincoln

Faculty Publications: Department of Entomology

July 1997

\title{
Insect Pests and Arthropod Predators Associated with Tree-Turf Landscapes
}

Mary Ellen Dix

USDA Forest Service

Frederick P. Baxendale

University of Nebraska-Lincoln, fbaxendale1@unl.edu

Follow this and additional works at: https://digitalcommons.unl.edu/entomologyfacpub

Part of the Entomology Commons

Dix, Mary Ellen and Baxendale, Frederick P., "Insect Pests and Arthropod Predators Associated with TreeTurf Landscapes" (1997). Faculty Publications: Department of Entomology. 142.

https://digitalcommons.unl.edu/entomologyfacpub/142

This Article is brought to you for free and open access by the Entomology, Department of at DigitalCommons@University of Nebraska - Lincoln. It has been accepted for inclusion in Faculty Publications: Department of Entomology by an authorized administrator of DigitalCommons@University of Nebraska - Lincoln. 


\title{
Insect Pests and Arthropod Predators Associated with Tree-Turf Landscapes 1,2
}

\author{
Mary Ellen Dix ${ }^{3}$, and Frederick Baxendale 4 \\ USDA FS Rocky Mountain Research Station \\ National Agroforestry Center \\ East Campus, University of Nebraska \\ Lincoln, NE 68583-0822 U.S.A.
}

\begin{abstract}
J. Entomol. Sci. 32(3): 257-271 (July 1997)
ABSTRACT Sweep-nets and pitfall traps were used to examine the distribution and dynamics of predominant predators and pests in turfgrass foliage in parks, golf courses and suburban/rural landscapes in 1991 and 1992. Araneae, Formicidae, and Coccinellidae were the most abundant predators in the sweeps, while Araneae, Formicidae, and) Carabidae were the most abundant predators in the pitfall traps. In both years, Araneae comprised over $60 \%$ of the total predators in the sweep samples. Formicidae $(>70 \%)$ and Araneae (13-19\%) were the most abundant arthropod predators in the pitfall samples. Cicadellidae, Chrysomelidae, and Orthoptera accounted for over $96 \%$ of the prey in the sweep samples, while Cicadellidae, Orthoptera (grasshoppers and crickets), and Aphididae comprised over $90 \%$ of the prey in the pitfall samples. Abundance of predators and prey, and prey / predator ratios fluctuated with site, date, and distance from the trees. During the season, high prey / predator ratios usually preceded peak prey abundance in the sweep samples. Predators usually were more prevalent in sweep samples closer to tree borders, while prey populations tended to be higher at distances further from the tree borders. These results suggest that tree borders provide food, shelter, and refuge for predators during periods of environmental stress.
\end{abstract}

KEY WORDS Urban landscapes, windbreaks, turfgrass, biological control, predators, parasites

Urban landowners traditionally have relied on synthetic pesticides to control landscape pests. Not surprisingly, urban landscapes have one of the greatest pesticide use rates and some of the most acute environmental contamination problems of any landscape in North America (McEwen and Madder 1986). This extensive use of pesticides has resulted in insect resistance to pesticides, unintentional injury to users and nontarget organisms, and contamination of soil and drainages in yards, in public parks, and along streets. Moreover, increasing

1 Received 18 June 1996; Accepted for publication 06 April 1997.

2 Use of trade names does not imply endorsement of products named nor criticism of similar ones not mentioned.

3 Research Entomologist.

4 Extension Entomologist, Department of Entomology, 212 Plant Industry Building, East Campus, University of Nebraska, Lincoln, 68583-0816 U.S.A. 
legal restrictions on pesticide use and public concern regarding environmental contamination likely will limit pesticide use in the future. The use of trees and their associated vegetation to enhance natural enemy populations is an alternative for managing insect pests in the urban landscape.

Trees and their associated understory vegetation enhance urban landscapes by providing food and protection for turf and tree pests and their natural enemies. Information on the use of trees by arthropods has been reported for several crop pests and their predators. For example, certain species of coccinellids and chrysomelids overwinter beneath the trees and understory vegetation (Balduf 1929, Hemptinne 1988, Mahr and Ridgeway 1993). In Texas, the boll weevil, Anthonomus grandis Boheman (Coleoptera: Curculionidae), overwinters in leaves and debris beneath shelterbelt trees (Slosser et al. 1984). Pond cypress (Taxodium ascendens Brongn.) planted around rice (Oryza sativa L.) and wheat (Triticum aestivum L.) fields in China mitigates adverse climatic conditions and provides habitat for spider (Arachnida: Araneida) species that control leafhopper (Homoptera: Cicadellidae) populations (Shi and Gao 1986).

However, information on the influence of trees on turf-inhabiting predators and prey is limited, yet this information is critical to alternative pest management strategies that enhance natural enemy populations. The objective of this research was to obtain essential baseline information by identifying common families or classes of arthropod predators and arthropod phytophagous prey in the turf foliage associated with turfgrass foliage in parks, golf course fairways and suburban / rural landscapes, determining their distribution and abundance, and describing their seasonal occurrence.

\section{Materials and Methods}

Sample locations. In 1991 and 1992, we selected six sites in Lancaster Co., NE with ponderosa (Pinus ponderosa Laws.) or Austrian (Pinus nigra Arnold) pines growing adjacent to tall fescue (Festuca arundinacea Schreb.) or bromegrass (Bromus sp.) stands. Two sites were adjacent to golf course fairways (GC1 and GC2), and two sites were located in city parks (P1 and P2). A fifth site was a suburban bromegrass meadow (WB1). A sixth site (WB2) was located at the University of Nebraska Agriculture Research and Development Center (ARDC) Turfgrass Research Facility near Ithaca in Saunders Co., NE.

Turfgrass management at the different study sites ranged from relatively intensive maintenance with regular fertilization and mowing (GC2, GC1), to minimal maintenance with little fertilization and infrequent mowing (WB1 and WB2). Maintenance at P1 and P2 was intermediate and consisted of occasional fertilization and mowing. Insecticides were not used at any of the sites. Tree heights ranged from 6 to $10 \mathrm{~m}$ and varied within and among sites. Trees at GC1, WB1, and P1 averaged over $7 \mathrm{~m}$ in height, wheras trees at the other sites averaged less than $7 \mathrm{~m}$.

Net sweep samples. Net sweeps were used to sample the effect of distance from trees on populations of arthropods inhabiting turfgrass foilage. This method collects sparsely dispersed species in foliage at one point in time (Southwood 1978) and is commonly used to sample for turf pests (Baxendale, unpubl. data). Turfgrass stands were swept 100 times with a standard 38-cm sweep net at distances 
of $0,0.5,2$, and 5 times tree height $(\mathrm{H})$ from the tree. Sweep samples were taken along transects (approximately $100 \mathrm{~m}$ long) parallel to the tree row. On each sampling date, one sweep sample (100 sweeps) was taken per site at each distance. The $0 \mathrm{H}$ sweeps were obtained under the trees' drip line and as close to trunks as possible. Sweeps at $0.5 \mathrm{H}$ usually fell near the outer drip line of the tree. The $5 \mathrm{H}$ sweep was well into the turf stand and was at least 7-10 $\mathrm{H}$ from all other surrounding trees. Because the $0 \mathrm{H}$ and $0.5 \mathrm{H}$ sweeps were under or immediately next to the tree, these samples were combined to give a "near tree" estimate for distances $\leq 0.5 \mathrm{H}$. Sweep samples were immediately placed in plastic bags and transferred to $70 \%$ alcohol for storage.

Pitfall trap samples. Pitfall traps were selected to sample ground-dwelling arthropods because they operate over extended time, collect diurnal and noctural arthropods, can be used in diverse habitats, and provide an indication of surface activity (Esau and Peters 1975). Pitfall traps consisted of a 0.5 -L plastic cup sunk into the ground (Morrill 1975). Inside this cup was placed a second 0.1-L plastic cup containing a $30 \%$ solution of Sierra Brand ${ }^{\circledR}$ antifreeze. A cone-shaped plastic cup with the basal end cut off was used as a funnel. At each site, a northern transect was marked from under each of five pines to approximately $150 \mathrm{~m}$ into the turf. Pitfall traps were placed at distances of $0 \mathrm{H}, 0.5 \mathrm{H}, 2 \mathrm{H}$, and $5 \mathrm{H}$ along each transect. The $0 \mathrm{H}$ pitfall was under the tree's drip line and as close to the trunk as possible. Pitfalls at $0.5 \mathrm{H}$ usually fell near the drip-line of the tree. The $5 \mathrm{H}$ pitfalls were well into the turf stand and were at least 7-10 $\mathrm{H}$ from all other surrounding trees. Because the $0 \mathrm{H}$ and $0.5 \mathrm{H}$ pitfalls were under or immediately next to the tree, these samples also were combined to give a "near tree" estimate for distances $\leq 0.5 \mathrm{H}$. Sites were sampled weekly from June through October 1991 and monthly from May through September 1992. Samples were returned to the laboratory and stored in 70\% ethanol for later identification and counting. Collected arthropods were categorized as carnivorous arthropod predators or herbivorous arthropod prey. Arthropods were identified by James Kalish and Robert Roselle, diagnosticians for the University of Nebraska Plant and Pest Diagnostic Clinic.

Data analysis. Arthropod collections from sweeps and pitfall traps were summarized for each site by year. For each year and site, predator and prey catches at different distances or "H" were analyzed using the PROC GLM procedure of SAS (SAS Institute 1992). Tukey's studentized range tests $(\alpha=0.05)$ were used to compare abundance among distances. Within-year temporal variation was used as the error term for the sweep analyses. Five transects per site were used to estimate error for pitfall analyses.

\section{Results}

Foliage sweeps / abundance. Spiders and ants (Hymenoptera: Formicidae) were the predominant predators collected in turfgrass sweep samples in both 1991 and 1992 (Table 1) and accounted for over $80 \%$ of the total predators. Spiders alone represented $60.1 \%$ and $64.5 \%$ of the total predators in 1991 and 1992 , respectively. Lady beetles (Coleoptera: Coccinellidae), lacewings (Neuroptera), minute pirate bugs (Orius tristicolor (White)), big-eyed bugs (Lygaeidae), rove beetles (Staphylinidae), syrphids (Syrphidae), harvestmen (Arachnida: Opiliones), and an assortment of other predators made up $6.4 \%$ and $14.3 \%$ of the total catch in 
Table 1. Arthropod predator and prey groups collected in sweep samples from several tree-turf sites in Lancaster Co. and Saunders Co., NE.

\begin{tabular}{|c|c|c|c|c|}
\hline \multirow[b]{2}{*}{ PREDATORS } & \multicolumn{2}{|c|}{1991} & \multicolumn{2}{|c|}{1992} \\
\hline & Number & $\begin{array}{c}\text { Percent of } \\
\text { total }^{*}\end{array}$ & Number & $\begin{array}{c}\text { Percent of } \\
\text { total* }\end{array}$ \\
\hline Spiders & 3,046 & 60.1 & 831 & 64.5 \\
\hline Ants & 1,769 & 34.9 & 240 & 18.6 \\
\hline Lady beetles & 80 & 1.6 & 34 & 2.6 \\
\hline Lacewings & 45 & 0.9 & 21 & 1.6 \\
\hline Minute pirate bugs & 43 & 0.9 & 24 & 1.9 \\
\hline Rove beetles & 41 & 0.8 & 0 & 0.0 \\
\hline Big-eyed bugs & 27 & 0.5 & 0 & 0.0 \\
\hline Harvestmen $* *$ & 14 & 0.3 & - & - \\
\hline Syrphids & 7 & 0.1 & 139 & 10.8 \\
\hline Other predators & 0 & 0.0 & 0 & 0.0 \\
\hline Total predators & 5,072 & 100.1 & 1,289 & 100.0 \\
\hline \multicolumn{5}{|l|}{ PREY } \\
\hline Leafhoppers & 2,7768 & 72.9 & 8,169 & 76.0 \\
\hline Flea beetles & 6,776 & 17.8 & 1,528 & 14.2 \\
\hline Grasshoppers & 1,837 & 4.8 & 650 & 6.0 \\
\hline Aphids & 1,287 & 3.4 & 184 & 1.7 \\
\hline Chinch bugs & 400 & 1.0 & 21 & 0.2 \\
\hline Armyworms and cutworms & 8 & 0.02 & 25 & 0.2 \\
\hline Other prey $^{\dagger}$ & 8 & 0.02 & 0 & 0.0 \\
\hline Total prey & 38,084 & 99.94 & 10,782 & 100.0 \\
\hline
\end{tabular}

* Percents do not add up to 100.0 because of rounding errors.

** Includes both predatory and nonpredatory harvestmen.

$\ddagger$ Other prey = wireworms, May/June beetles and masked chafers.

1991 and 1992, respectively. The Opiliones include both predatory and nonpredatory species.

Leafhoppers (Homoptera: Cicadellidae), flea beetles (Coleoptera: Chrysomelidae), and grasshoppers (Orthoptera) were the predominant prey species in both years and represented 96\% of prey species collected in both 1991 and 1992 (Table 1, Fig. 1). The remaining $4 \%$ consisted of aphids (Homoptera: Aphididae), chinch bugs (Blissus leucopterus leucopterus (Say)), armyworms (Pseudaleta unipuncta (Haworth)), cutworms (Lepidoptera: Noctuidae), and a few additional prey species. Grasshoppers were more numerous at minimally maintained sites (WB1 and WB2). In 1991, leafhoppers tended to be more numerous in parks; whereas fleas beetles 
1991 Sweeps

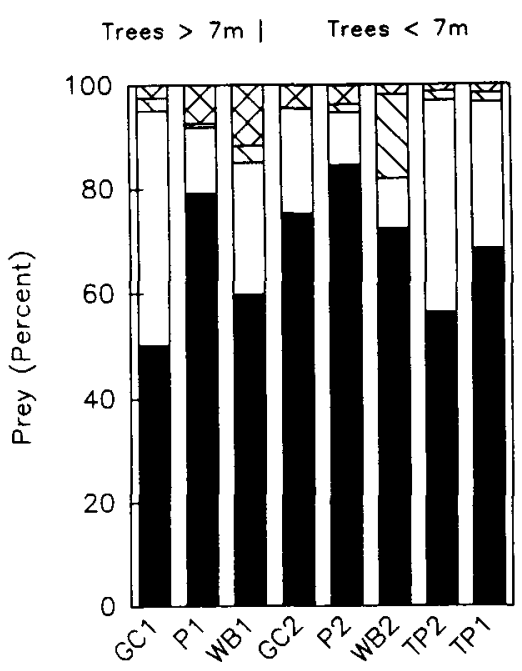

Sites
1992 Sweeps

Trees $>7 \mathrm{~m} \mid$ Trees $<7 \mathrm{~m}$

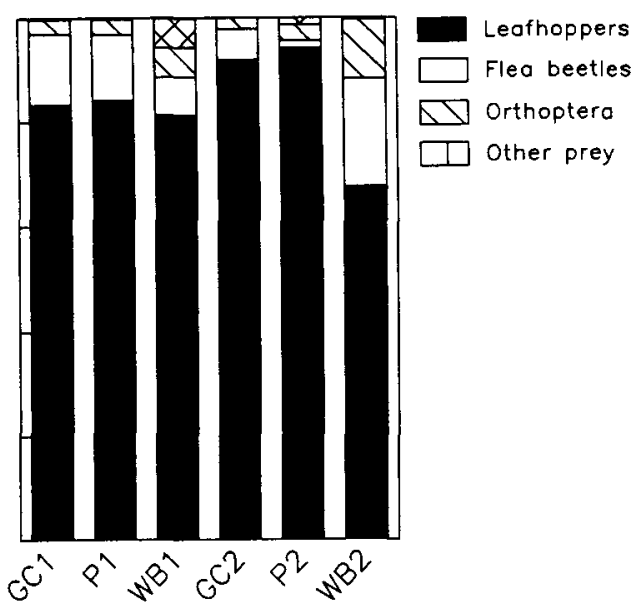

Site

Fig. 1. 1991 and 1992 prey abundance, as a percentage of total prey, in sweep samples from six tree-turf sites in eastern Nebraska

were more numerous on golf courses. However, no pattern was discernable in 1992 (Fig. 1).

Mean predator abundance per site averaged 8.4 and 7.2 specimens per 100 sweeps in 1991 and 1992, respectively (Fig. 2). Mean prey abundance in sweep samples averaged 60.3 and 68.1 in 1991 and 1992, respectively. Predators were generally more abundant at low-maintenance sites. Further, predator abundance tended to increase with decreasing maintenance at sites with trees smaller than or equal to $7 \mathrm{~m}$. In 1991, mean predators per 100 sweeps ranged from a low of 6.6 predators at GC2, a highly managed site, to highs of 11.6 and 11.8 predators at two sites with low maintenance (WB1 and WB2, respectively). In 1992, predator abundance was lower than 1991 at all sites except WB2 and ranged from 3.2 (GC2) to 9.1 (WB1) and 19.1 (WB2) predators per 100 sweeps.

In most cases, when comparing sites with trees of similar size, the sites with the lowest maintenance had more predators and prey than sites with high levels of maintenance. No trend by level of maintenance was observed in prey abundance at sites with trees taller than $7 \mathrm{~m}$ (Fig. 2).

Foliage sweep / prey / predator ratios. Turfgrass maintenance had little effect on potential prey / predator ratios on turf foliage (Fig. 2). In 1991, the lowest 


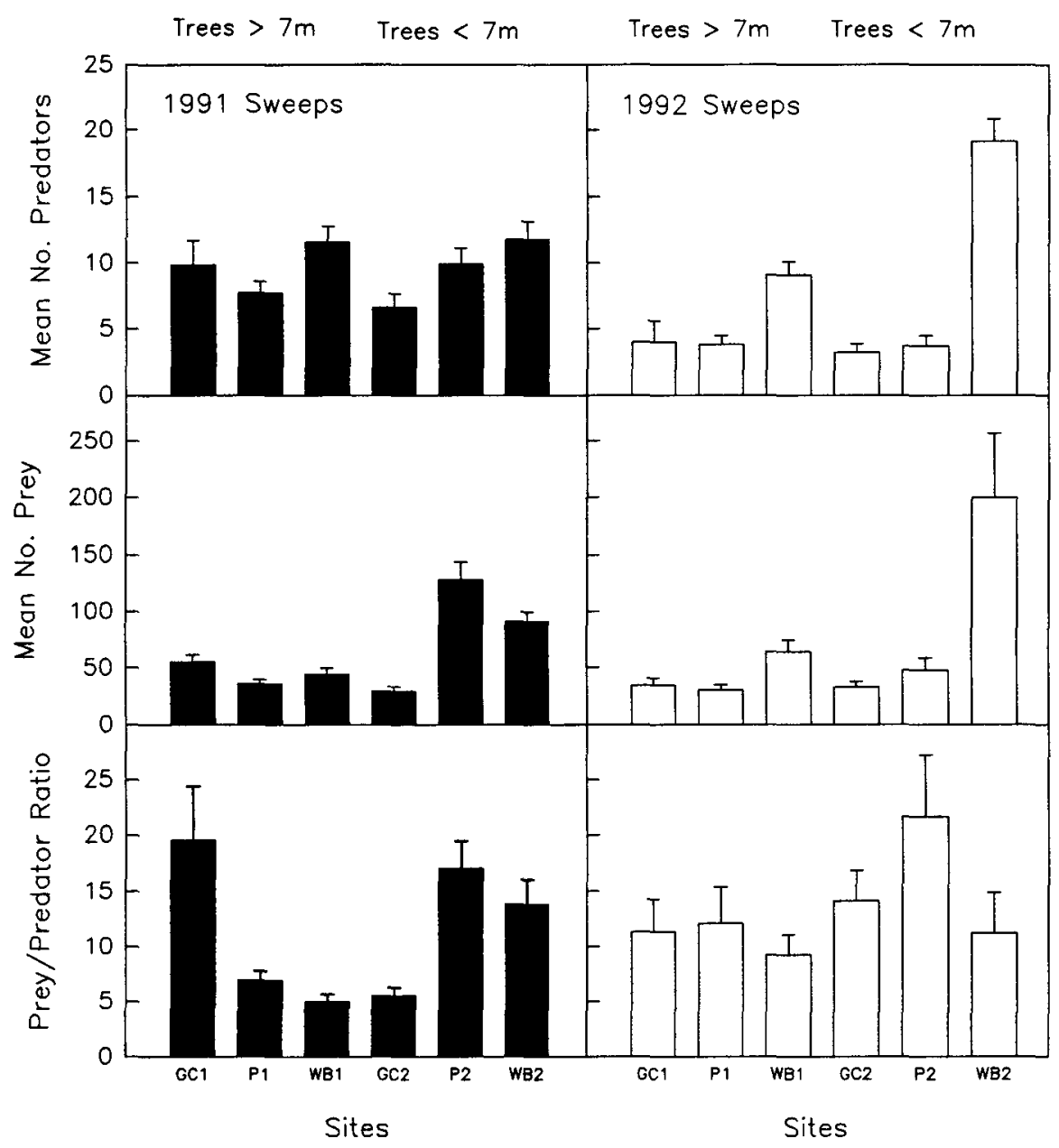

Fig. 2. Mean ( $\pm \mathrm{SE}$ ) predator, prey and prey / predator ratios in sweep samples at six tree-turf sites in Nebraska

ratios for sites with trees taller than $7 \mathrm{~m}$ occurred at WB1 and P1, sites with minimal and intermediate maintenance, respectively. For sites with trees smaller or equal to $7 \mathrm{~m}$, the lowest ratio was present at GC2, a high maintenance site. In 1992, the prey / predator ratio was lower but not statistically significant at WB1, a minimally maintained site, and insignificantly higher at P2, a site with intermediate maintenance levels. 
Foliage sweep / distance. Total arthropod abundance varied with distance from the tree (Fig. 3). In 1991, mean total arthropod abundance averaged 66.7, 89.7 and 69.8 at distances of $0.5 \mathrm{H}, 2 \mathrm{H}$ and $5 \mathrm{H}$, respectively. In 1992, mean total arthropod abundance increased with distance from the tree and was 53.2, 83.8 and 128.5 at distances of $0.5 \mathrm{H}, 2 \mathrm{H}$ and $5 \mathrm{H}$, respectively. Overall, predators were numerically most abundant at distances less than or equal to $0.5 \mathrm{H}$ in 1991 and at less than or equal to $0.5 \mathrm{H}$ and $2 \mathrm{H}$ in 1992. In 1991, predator abundance near the trees $(\leq 0.5 \mathrm{H})$ was significantly higher than at other distances for GC1 $(F=$ $7.34, P<0.05, \mathrm{df}=84)$ and WB2 $(F=5.69, P<0.05, \mathrm{df}=73)$ but was not significantly different near the trees at GC2 and P2. In addition, while predator abundance away from the trees $(5 \mathrm{H})$ was numerically higher for P1 and WB1, only P1 was significantly higher $(F=4.72, P<0.05$, $\mathrm{df}=81)$. In 1992 , predators abundance at distances less than or equal to $0.5 \mathrm{H}$ appeared to be numerically higher than the other distances for GC1, GC2, and P2. However, predator abundance was significantly higher $(F=3.49, P<0.05, \mathrm{df}=25)$ only for site WB2 at a distance of $2 \mathrm{H}$.

At most sites prey abundance seemed to be higher away from trees $(2 \mathrm{H}$ or $5 \mathrm{H}$ ) (Fig. 3). In 1991, prey abundance tended to be highest at distances of either $2 \mathrm{H}$ (GC1, WB1, P2, and WB2) or $5 \mathrm{H}$ (P1). However, prey abundance was significant $(F=5.48, P<0.05, \mathrm{df}=73$ ) only for WB2. In 1992 , prey abundance was numerically higher at a distance of $5 \mathrm{H}$ for all sites, but was only significant $(F=2.89, P<0.05$, $\mathrm{df}=25$ ) for $\mathrm{WB} 2$.

In 1991, prey / predator ratios were lowest near the tree $(\leq 0.5 \mathrm{H})$ and highest at distances of $2 \mathrm{H}$ or $5 \mathrm{H}$ at all sites (Fig. 3). However, these differences were not significant. Similarly, in 1992, prey / predator ratios in the sweep samples tended to be numerically lower at distances less than or equal to $0.5 \mathrm{H}$ (GC2, P1, P2, and WB2) and were numerically higher at distances of $2 \mathrm{H}$ (GC1, GC2, P1, and P2) or $5 \mathrm{H}$ (WB2).

Pitfall samples / abundance. Ants, spiders, carabids, rove beetles, and harvestmen were the predominant predators collected in the pitfall samples and comprised more than $96 \%$ of the total predator specimens collected in both years (Table 2). Ants accounted for over $71 \%$ of the total predator specimens, while spiders comprised $13 \%$ and $19 \%$ of the total predators in 1991 and 1992, respectively. Carabids (includes both predatory and nonpredatory species), minute pirate bugs, big-eyed bugs, rove beetles, harvestmen (includes both predatory and nonpredatory species), and an assortment of other predators accounted for the remaining 10 to $13 \%$ of the predators collected.

Leafhoppers, aphids, crickets, and grasshoppers were the predominant prey species and represented about $80 \%$ of prey specimens collected in both years (Table 2). Flea beetles, chinch bugs, billbugs, armyworms, cutworms, and a few miscellaneous prey species made up the remaining 20\%. Leafhoppers, flea beetles, grasshoppers, and aphids are normally associated with foliage and apparently fell into the traps while hopping or flying among their plant hosts. The remaining prey probably fell into the traps while crawling over the ground.

Mean predator abundance varied with year and site (Fig. 4). In 1991, mean predators per pitfall trap averaged 35.9 and ranged from a low of 26.2 predators per pitfall at GC1, a highly managed site, to a high of 62.9 at the P2 site with intermediate maintenance. In 1992, predator abundance averaged 15.7 per pitfall 


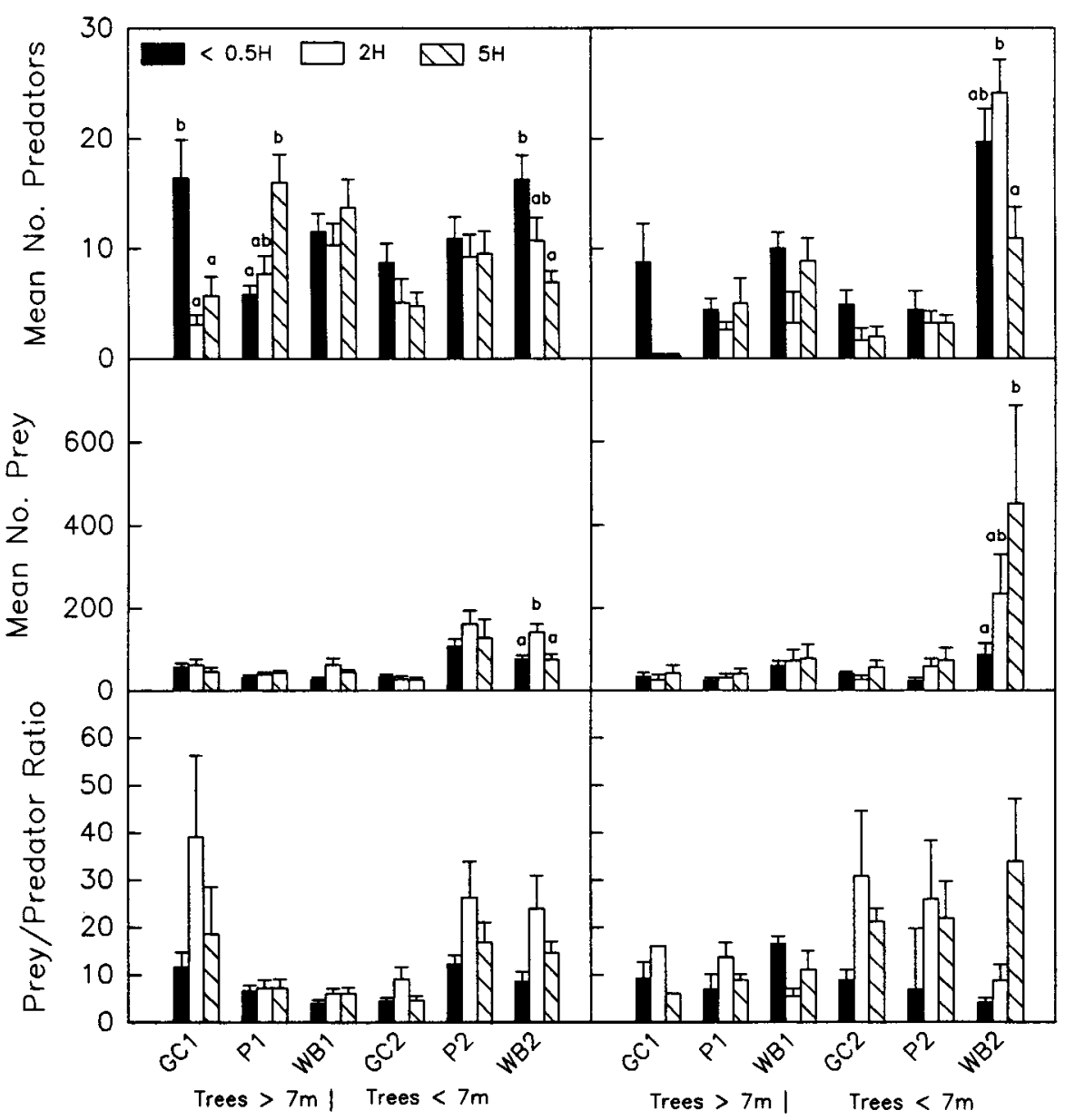

Sites

Fig. 3. Mean ( \pm SE) predator, prey and prey / predator ratios in sweep samples taken near the tree (distances $\leq 0.5$ times tree height $(\mathrm{H})$ from the tree), $2 \mathrm{H}$, and $5 \mathrm{H}$ at six tree-turf sites in Lancaster Co. and Saunders Co. NE. Bars within a site with different letters above them vary significantly $(P<0.05)$ according to Tukey's studentized range test.

and ranged from 4.4 predators per pitfalls at P1 to a high of 24.5 at WB2. No trend in predator abundance was observed in pitfall traps at sites with trees taller than $7 \mathrm{~m}$ or smaller than or equal to $7 \mathrm{~m}$. Spiders, ants, and carabids accounted for over $80 \%$ of the predators at the sites (Fig. 5). 
Mean prey abundance in pitfall samples varied with year and site (Fig. 4), and ranged from 1.3 (WB1) to 4.7 (WB2) in 1991, and from 2.0 (P1) to 3.8 (P2) and 20.3 (WB2) in 1992. In both years, prey abundance at sites with tree heights smaller than or equal to $7 \mathrm{~m}$ was highest at WB2, a site with minimal maintenance. At sites with tree heights greater than $7 \mathrm{~m}$, prey abundance was highest at P1 and did not vary among sites in 1992. Leafhoppers, accounted for at least $30 \%$ of the prey at all sites (Fig. 5). The abundance of aphids and grasshoppers (Orthoptera), the next two most abundant prey, varied with year and site.

Table 2 Arthropod predator and prey groups collected in pitfall samples from several treeturf sites in Lancaster Co. and Saunders Co., NE.

\begin{tabular}{|c|c|c|c|c|}
\hline \multirow[b]{2}{*}{ PREDATORS } & \multicolumn{2}{|c|}{1991} & \multicolumn{2}{|c|}{1992} \\
\hline & Number & $\begin{array}{l}\text { Percent of } \\
\text { total }^{*}\end{array}$ & Number & $\begin{array}{c}\text { Percent of } \\
\text { total }^{*}\end{array}$ \\
\hline$\overline{\text { Ants }}$ & 38,004 & 76.4 & 10,780 & 71.1 \\
\hline Spiders & 5,605 & 11.3 & 2,886 & 19.0 \\
\hline Carabids** & 3,253 & 6.5 & 596 & 3.9 \\
\hline Harvestmen** & 1,319 & 2.7 & 361 & 2.4 \\
\hline Rove beetles & 1,135 & 2.3 & 233 & 1.5 \\
\hline Minute pirate bugs & 158 & 0.3 & 153 & 1.0 \\
\hline Syrphids & 131 & 0.3 & 125 & 0.8 \\
\hline Big-eyed bugs & 69 & 0.1 & 17 & 0.1 \\
\hline Other predators $^{\dagger}$ & 94 & 0.2 & 18 & 0.1 \\
\hline Total predators & 49,768 & 100.1 & 15,169 & 99.9 \\
\hline \multicolumn{5}{|l|}{ PREY } \\
\hline Leafhoppers & 2,429 & 53.0 & 2,070 & 40.0 \\
\hline Aphids & 1,115 & 24.3 & 505 & 9.8 \\
\hline Grasshoppers and crickets & 329 & 7.2 & 2,157 & 41.7 \\
\hline Flea beetles & 282 & 6.2 & 112 & 2.2 \\
\hline Chinch bugs & 163 & 3.6 & 54 & 1.0 \\
\hline Mask chafer & 106 & 2.3 & 6 & 0.1 \\
\hline Billbugs & 83 & 1.8 & 82 & 1.6 \\
\hline Cutworms & 51 & 1.1 & 72 & 1.4 \\
\hline Armyworms & 8 & 0.2 & 34 & 0.7 \\
\hline Other prey & 17 & 0.4 & 81 & 1.6 \\
\hline Total & 4,583 & 100.1 & 5,173 & 100.1 \\
\hline
\end{tabular}

*Total percents do not add up to 100.0 , because of rounding errors.

**Includes both predatory and nonpredatory species.

†Other predators $=$ lady beetles, lacewings.

‡Other prey = May / June beetles, cutworms, black turfgrass ataenius. 


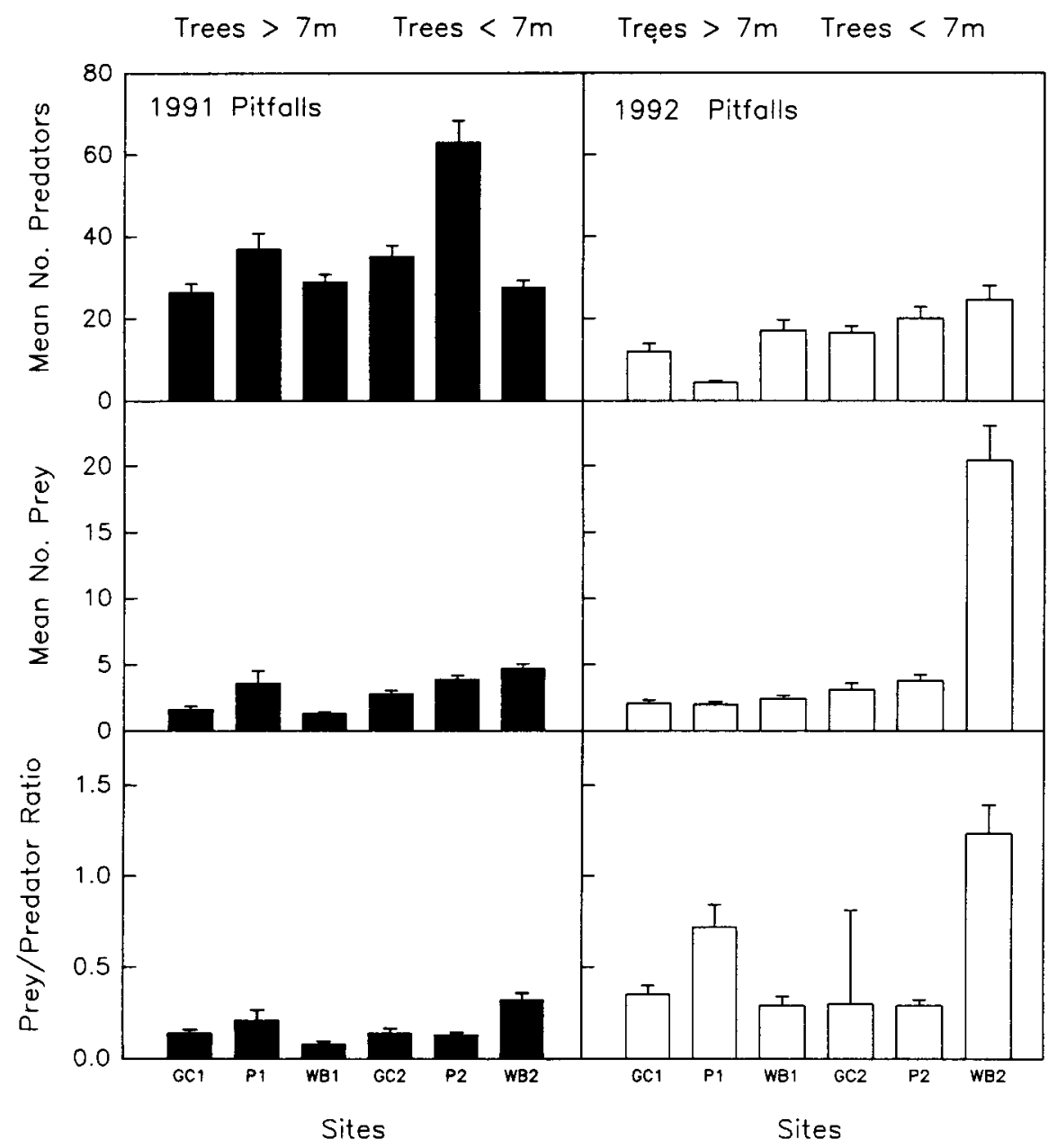

Fig. 4. Mean ( \pm SE) predator, prey and prey / predator ratios in pitfall samples at six tree-turf sites in eastern Nebraska.

Pitfall / distance. Arthropod abundance varied with distance from the trees (Fig. 6). In 1991, predator abundance was significantly higher ( $F$ range 4.31-35.03, $P<0.05$, df range 137-206) at $5 \mathrm{H}$ when compared to $0.5 \mathrm{H}$ at GC1, P1, WB1, P2, and WB2. In 1992, predators were significantly more abundant away from the trees only at P2 $(2 \mathrm{H})(F=2.7, P<0.10, \mathrm{df}=115)$ and at WB1 $(5 \mathrm{H})(F=11.9, P<$ 0.05 , $\mathrm{df}=141$ ). Although nonsignificant, 1992 predator abundance patterns at GC1 and GC2 were similar to those in 1991. Prey / predator ratios varied with site, and distance and no trend was evident among sites with similar height trees. 

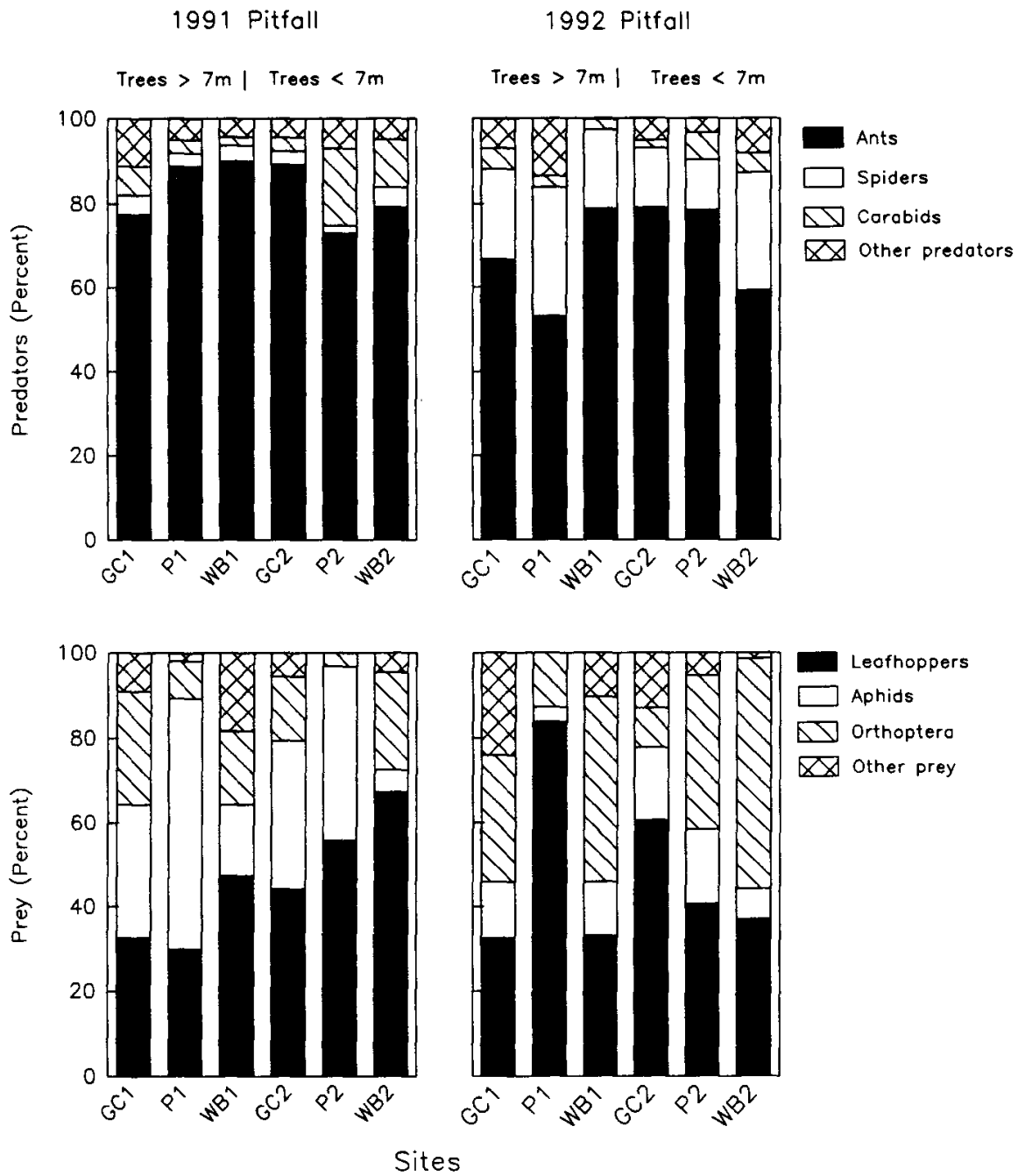

Fig. 5. 1991 and 1992 relative predator and prey abundance, as a percentage of total prey, in pitfall samples from six tree-turf sites in Lancaster Co. and Saunders Co.

\section{Discussion}

The arthropod community in Nebraska turfgrass is composed of diverse arthropod taxa, for which abundance varied with site and sampling method (Tables 1 and 2, Figs. 1 and 5). Similar diversity of arthropod communities has been reported in Kentucky, New Jersey, and Florida (Cockfield and Potter 1984a, Potter 1992). 


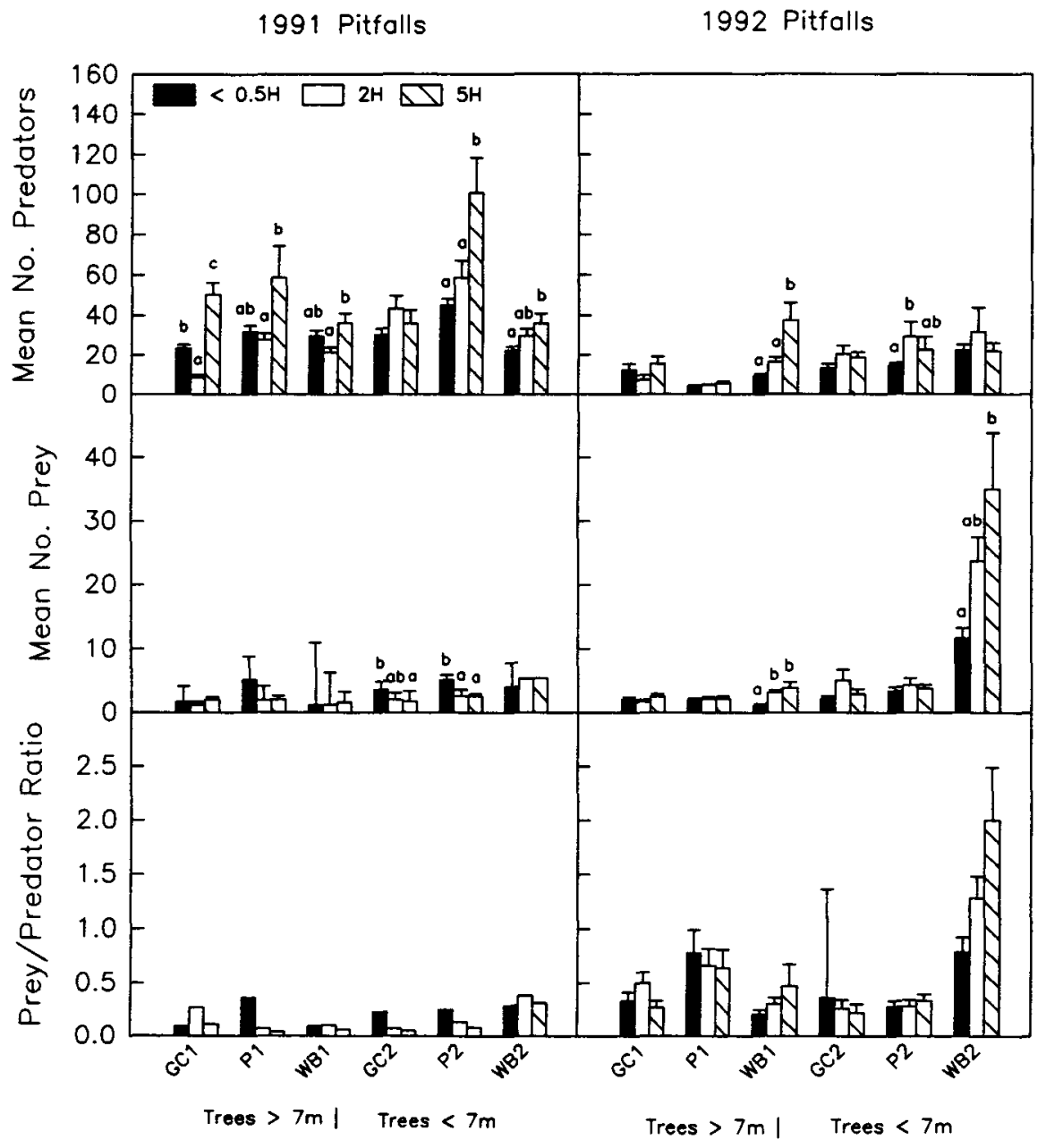

Sites

Fig. 6. Mean $( \pm \mathrm{SE})$ predator, prey and prey / predator ratios in pitfall traps placed near the tree (distances $\leq 0.5$ times tree height $(\mathrm{H})$ from the tree), $2 \mathrm{H}$, and $5 \mathrm{H}$ at six tree-turf sites in eastern NE. Bars within site with different letters above them vary significantly $(P<0.05)$ according to Tukey's studentized range test.

Pest outbreaks seldom occur in these diverse turfgrass landscapes, because natural enemies maintain pest populations below epidemic levels (Potter 1992). For example, ground-dwelling ants consumed or carried off up to $75 \%$ of the sod webworm eggs within $48 \mathrm{~h}$ of exposure in Kentucky (Cockfield and Potter 1984b). In 
our study, ants were the most abundant predator in pitfall traps at all sites. Although we did not determine their prey in Nebraska, the ants probably fed on aphids, mites, insect eggs, and other small arthropods.

Carabids also are important predators in the turf landscape. In Kentucky, carabids killed $60 \%$ of the armyworm pupae within $48 \mathrm{~h}$ with each carabid usually consuming multiple larvae (Potter 1992). Carabids comprised less than $7 \%$ of the total predators in the pitfall traps from Nebraska. However, their predation potential is substantial because of their size and number of prey consumed. Furthermore, spiders, carabids, and rove beetles together accounted for over $20 \%$ of the total predators in both years. Predation by ants, carabids, spiders, and rove beetles probably contributes to suppressing prey infestations below outbreak levels.

Predators in sweep samples at most sites were more abundant within the drip line or at distances less than or equal to $5 \mathrm{H}$ from the tree whereas prey were more abundant at distances of $2 \mathrm{H}$ and $5 \mathrm{H}$ from the trees. In pitfall traps at GC1 and WB2 in 1991 and at all sites (except WB2) in 1992, predators were most abundant at those distances with high prey abundance in the pitfall samples. Both predators and prey were more abundant in pitfall traps away from the trees at sites with trees taller than $7 \mathrm{~m}$. These ground-dwelling predators were highly mobile generalist feeders whose hunting territory potentially could have included both under the tree and at distances of $5 \mathrm{H}$. This was especially evident at sites with tree heights less than or equal to $7 \mathrm{~m}$; but no significant trend in either predator or prey abundance in pitfall traps could be discerned within the sites. However, at sites with tree heights greater than $7 \mathrm{~m}$, predator and often prey populations were highest at $5 \mathrm{H}$, where tree influence would be expected to be lower.

Spider populations did not significantly diminish over the season at several of these sites, indicating that trees may act as a refuge for the spiders. However, ant abundance did fluctuate among sites.

Leafhoppers were the predominant prey caught in both sweep samples and pitfall traps. Large leafhopper populations are commonly associated with turf; however, they generally are considered only minor pests (Byers and Jung 1979). Leafhoppers and flea beetles have been found to be the most abundant in fertilized pastures and forage grasses where levels of nitrogen were high in the foliage (Byers and Jung 1979). Thus, large numbers of these insects would be expected on turf sites with intensive lawn care such as golf courses; but we observed the reverse. Leafhoppers were more numerous on minimally maintained sites and their abundance was lower on golf courses and other highly fertilized sites. Leafhopper abundance can fluctuate radically in response to physiological and mechanical events with populations ranging from high one week to near zero the next (Lamp et al. 1989). We also observed this wide fluctuation in leafhopper abundance among sample sites, possibly because of mowing.

In conclusion, predator and prey populations in the urban landscape vary extensively among and within sites and throughout the season. Availability of alternative prey in the landscape, environmental stresses, and a decrease in predator abundance all may have an impact on prey abundance. Foliage-dwelling predators seemingly use trees and associated vegetation for food and shelter, and tended to concentrate in or near the trees. Ground-dwelling predators were found to be more abundant away from the trees especially at sites with trees taller than $7 \mathrm{~m}$. These results provide baseline information on the distribution of common 
arthropod predators and prey in tree-turf landscapes. This information is crucial part of pest management strategies for enhancing natural enemy populations.

\section{Acknowledgments}

The authors wish to thank L. Gustafson, M. Gustafson, E. Pfeifer, T. Weinhold, R. Roselle, M.-S Kim, T. Hovland, and J. Irwin for their technical assistance, R. King and L. Young for their statistical review of the manuscript, and N. Klopfenstein, J. Zhang, M. Harrell, S. Danielson, R. Wright, S. Quisenberry, R. Cunningham, E. Hart, and M. Schoeneberger for their technical reviews of the manuscript. Research was supported in part by the University of Nebraska Agriculture Experiment Station Project NEB-17-062. This is paper 11545 of the journal series of the Agricultural Research Division, University of NebraskaLincoln. Voucher specimens are deposited in the Great Plains Tree Insect Collection located at the USDA Forest Service Rocky Mountain Forest and Range Experiment Station, National Agroforestry Center, East Campus, University of Nebraska, Lincoln NE.

\section{References Cited}

Balduf, W. V. 1929. Hibernation of the striped cucumber beetle (Coleoptera: Chrysomelidae). Entomological News. Oct. 1929 40: 260-262.

Byers, R. A. and G. A. Jung. 1979. Insect populations on forage grasses effect of nitrogen fertilizer and insecticides. Environ. Entomol. 8: 11-18.

Cockfield, S. D. and D. A. Potter. 1984a. Predatory insects and spiders from suburban lawns in Lexington, Kentucky. The Great Lakes Entomol. 17: 179-184.

1984b. Predation on sod webworm (Lepidoptera: Pyralidae) eggs as affected by chlorpyrifos application to Kentucky bluegrass turf. J. Econ. Entomol. 77: 1542-1544.

Esau, K. L. and D. C. Peters. 1975. Carabidae collected in pitfall traps in Iowa cornfields, fencerows and prairies. Environ. Entomol. 4: 509-513.

Hemptinne, J. L. 1988. Ecological requirements for hibernating Propylea quatuordecimpunctata and Coccinella septempunctata (Coleoptera: Coccinellidae). Entomophaga 34: 505-515.

Lamp, W. O., M. J. Morris and E. K. Armbrust. 1989. Empoasca (Homoptera: Cicadellidae) abundance and species composition on habitats proximate to alfalfa. Environ. Entomol. 18: 423-428.

Mahr, D. L. and N. M. Ridgway. 1993. Biological control of insects and mites. North Central Regional Publication $481.91 \mathrm{pp}$.

McEwen, F. L. and D. J. Madder. 1986. Environmental impact of pesticide use, pp. 25-50. In G. W. Bennett and J. M. Owens (eds.), Advances in urban pest management. Van Nostrand Rienhold Co. New York.

Morrill, W. L. 1975. Plastic pitfall trap. Environ. Entomol. 4: 596.

Potter, D. A. 1992. Natural enemies reduce pest populations in turf. USGA Green Section Record: November-December 1992.

SAS Institute. 1992. SAS technical report P-229 SAS/STAT software: changes and enhancements 6.07. SAS Institute Inc., Cary, NC.

Shi, Z. and Z. Gao. 1986. On the ecological efficiency of shelterbelt network and its yield increasing effect in paddy fields. J. Ecol. 5: 10-14.

Slosser, J. E., R. J. Fewin, J. R. Price, L. J. Meinke and J. R. Bryson. 1984. Potential of shelterbelt management for boll weevil (Coleoptera: Curculionidae) control in the Texas rolling plains. J. Econ. Entomol. 77: 377-385.

Southwood, T. R. E. 1978. Ecological methods, 2nd edition, Chapman and Hall. New York. 